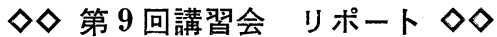

小 汀 政 德*

\section{I. 情報の提供の背景とその方法}

ここ数年文献情報の量が急激に増加してき たことは周知の事実である。これに伴って学 術文献の処理と，必要とする情報資料を研究 者等利用者側から，図書館員や情報担当者に でさるだけ早く整備してもらいたいといら要 望がたかまっている。それといらのも利用者 側からすれば，(1)各種文献を調査する時間が ない。(2)すへて必要と思われる文献が自分の 手もとに綱羅的に収集，入手することが困難 になってきたし経費及び労力という問題でと いらことが上げられる。

これを情報資料提供者の側から考察してみ ると，我々の基本的な姿勢は(1)まず何のため に情報を提供するのか，(2)相手が要求してい るのは具体的にどのようなものであるかとい うことの判断である。従って提供者と利用者 の接点に於いて, 図書館の資料の貸出, 閲覧展 示, 回覧等の毎日の業務方法以外に reference work がある。情報提供の方法としてその他 に相互貸借，タイトルリストによる提供，コ ンテンツシートによる提供方法，目録による 提供, Index類 abstract類による資料の提供, その他翻訳, 複写, 年報等出版による提供方法 が行われている。しかしこの内で active な Reference work が一番遅れている問題であ り，又情報文献の増加に対処するには一番早 く解決を迫まられている問題であると思う。

\section{Referencer}

Reference work を論ずる以前, 研究員等資
料利用者が図書室は如何なる情報提供を行っ ているかよく知られていないことが多い，又 図書室側として個々の研究者が現在いかなる 研究しているかといらことを網羅的に知るこ とは不可能である。研究報告等でどのような テーマを研究しているかといらことは調査で きるが，その個々についての専門的知識を追 うことは時間的にも不可能だ。このようなこ とが日本專門図書館に於いて未だ Reference work が充分図畫館に任されない土壤があ るといえそらである。しかし，MEDLARS のよらな機械文献採索の方法がいやおらなし に我々に押しつけられると，それに対してい かなる態度で臨むかといら姿勢を決めなけれ ばいけない。

現在 Special Librarian 又は documentalist と呼ばれる情報処理者の養成が叫けばれてい る。筆者は Library に勤務する以前，実験 室にいたときの経験より，Referencerは次の ことの充分留意すべきだと思う。

(1)利用者の意向を充分に把握すること。

Special Librarian or documentalist に要 求されるのは幅広い専門的知識である（特に 製薬会社の場合化学, 薬学, 医学までにその 範囲が及ぶ)。ところが情報利用者が求めてい るのはある領域のごく一部分のことを深く研 究していることが多い。そこで考它られるこ とに提供した情報が利用者の真に求めている のものかということである。研究者にとって 自分が真に必要とした情報といらものは大変 有難いものであるが，わずかに的を外れてい る information は机上に積み上げられるか， 
ゴミ箱行がオチであり，時には不快感さえむ 与觉る結果となる。（これは専門的知識の末 熟な段階に当然考兄られる性質のものだ）調 査段階に於いて依頼者と充分意見を交換する ことが大切だ。

(2) Terminology

文献探索が早く正確に進行するのはSpecial term を熟知している度合によるといって も過言でないと思う。日常 Science, nature, Naturwissenschaften, usw. の general な journal を熟続して Scientific Topicsを豊富 にすることも一対策であろら。又各国の各種 学会誌を読んで論文形式を研究することも Terminology の知識を増加させると思う。

(3) Reference Tools

依頼された調査事項に対して早く処理する ことは技術の一つである。Reference Tool と して用いられる Index 類, Abstract 類の構 造，その引き方等を熟知するといらことは当
然の義務である。それらの構造は年々修正さ れることがあるので充分注意する必要がある と思う。

\section{III. 医学薬学図書館講習会への期待}

今年の講習会は医学の Reference workに ついて主に実施されたが， medical terminology 各書誌学の 講義を後半の Reference work に役立つよら結びつけて行われたらも っと効果があったにちがいない。 medical terminology の講義は時間の都合もあった か乎知れないが余りに羅列的に終ってしまっ た。termといらものは早期に覚えられるも のでないが各書誌学の中に Librarianとして 必要な語はこらいうものだとか，その分野に 於ける権威ある畫誌はこらいうものだという ような解説があれば講習会の講義科目との関 連性がもたれて意義あるもになったと思いま 5。

\section{DEWEY 17-D. C. 第 17 版出版 DEWEY Decimal Classification and Relative Index}

Edition 17 in 2 Volumes

1965, 2153 pages (Forest Press, Inc., N. Y.) 〈近日入荷〉概価 $\mathbf{1 3 , 5 0 0}$

図書分類史上不朽の名を伝光る Melvil Dewey の Decimal Classification（略称 D. C.) は 1876 年初版を発行以来，すでに 16 版を重叔，いわゆる標準分類表と して，世界的に利用されていますが，今回待望の第 17 版が出版され，近日入荷， 発売されます。新 17 版は 1958 年出版の第 16 版を增補改訂したもので

1）第 16 版への追加，注釈等の新版書への収録

2) 新しい主題の插入と展開

3) “心理学” の項の全面的改訂

4) Form Division に代る Standard Subdivision Table の充実

5）地理区分のための Area Table の新設

6) D. C. の最大の特長である Relative Index（相関索引）の全面的な新編集 などが，大きな特長として挙げられます。

図書館業務の最も基本的なトウールとして，D. C. を使用している図書館はもと より，大学図書館，公共図書館，専門図書館などにぜひお備えのほど括すすめいた します。 